\title{
CD8 $\alpha+$ dendritic cells dictate immune responses against murine AML
}

\author{
Douglas E Kline ${ }^{1,2^{*}}$, Dominick Fosco ${ }^{2}$, Xiufen Chen ${ }^{2}$, Justin Kline ${ }^{1,2}$ \\ From Society for Immunotherapy of Cancer 28th Annual Meeting \\ National Harbor, MD, USA. 8-10 November 2013
}

Spontaneous $\mathrm{T}$ cell responses generated against a variety of solid malignancies are often subverted by immune evasion mechanisms active in the tumor microenvironment. In contrast, the mechanisms that regulate $\mathrm{T}$ cell activation versus tolerance to hematopoietic malignancies, such as acute myeloid leukemia (AML), have not been well-characterized. Our recent work in a murine AML model has demonstrated that following a systemic introduction of leukemia cells, $\mathrm{T}$ cells specific for leukemia-derived antigens underwent abortive proliferation and were deleted from the host. This deletional tolerance in mice with established AML was reversible upon administration of an agonistic anti-CD40 antibody to activate host dendritic cells (DCs), and argued that these cells may play a dominant role in tolerance induction to AML. Investigation of the DCs populations which engulfed AML cells in vivo, and which were likely promoting $\mathrm{T}$ cell tolerance, led to the critical observation that AML cells were phagocytosed exclusively by CD11c $+\mathrm{CD} 8 \alpha+\mathrm{DCs}(\mathrm{CD} 8 \alpha+\mathrm{DCs}) \cdot \mathrm{CD} 8 \alpha+$, but not CD $8 \alpha-$ DCs purified from mice following an intravenous inoculation of AML cells, were able to cross-present leukemia-derived antigens to $\mathrm{T}$ cells in vitro, providing strong evidence that CD8 $\alpha+\mathrm{DC}$ generate $\mathrm{T}$ cell tolerance to AML. Ongoing work utilizing mice deficient in particular DC subsets is focused on identifying a functional link between CD $8 \alpha+$ DCs and T cell tolerance. Additionally, the receptors expressed selectively on CD $8 \alpha+$ DCs which facilitate phagocytosis and cross-presentation of leukemia derived antigens are under investigation.

\footnotetext{
Authors' details

${ }^{1}$ Committee on Immunology, University of Chicago, Chicago, IL, USA.

2Department of Medicine, University of Chicago, Chicago, IL, USA.
}

Committee on Immunology, University of Chicago, Chicago, IL, USA

Full list of author information is available at the end of the article
Published: 7 November 2013

doi:10.1186/2051-1426-1-S1-P158

Cite this article as: Kline et al:: $C D 8 \alpha+$ dendritic cells dictate immune responses against murine AML. Journal for ImmunoTherapy of Cancer 2013 1(Suppl 1):P158
Submit your next manuscript to BioMed Central and take full advantage of:

- Convenient online submission

- Thorough peer review

- No space constraints or color figure charges

- Immediate publication on acceptance

- Inclusion in PubMed, CAS, Scopus and Google Scholar

- Research which is freely available for redistribution

Submit your manuscript at www.biomedcentral.com/submit
C Biomed Central
C Biomed Central

(c) 2013 Kline et al; licensee BioMed Central Ltd. This is an Open Access article distributed under the terms of the Creative Commons Attribution License (http://creativecommons.org/licenses/by/2.0), which permits unrestricted use, distribution, and reproduction in any medium, provided the original work is properly cited. 